\title{
Corruption, Ritualism and Prophetic Role of the Catholic Church
}

\author{
Antonius Galih Arga W. Aryanto, Martinus Joko Lelono \\ Universitas Sanata Dharma, Yogyakarta \\ email: galiharga@usd.ac.id,martinusjoko@gmail.com
}

\begin{abstract}
This interdisciplinary study attempts to relate corruption with the Catholic Church's role as the moral and social critics that compel believers to participate in confronting corruption and bribery. The interdisciplinarity is also the method applied in the study. It includes an exposition of the economic data of the GDP, its theological interpretation based on the story of Naboth and the king in the Old Testament, and strategic action field theory. The article begins with widespread corruption in ASEAN, then continues with a theological foundation for believers' role as guardians of moral and social values. The Church, however, faces ritualism and religious formalism that cause faith values do not influence to eradicate corruption. Finally, by implementing the social study of Strategic Action Field (SAFs) theory, the paper proposes an anti-corruption movement as a strategic action for the Catholic Church to tackle corruption. The study found that the social study of Strategic Action Field (SAFs) theory allows the Church to develop the anti-corruption movement as the strategic action to create pastoral works to tackle corruption.
\end{abstract}

Keywords: ASEAN Church, Corruption, Catholic Church, moral, social critics, Strategic Action Fields

\begin{abstract}
Abstrak: Kajian interdisipliner ini mencoba mengaitkan korupsi dengan peran Gereja Katolik sebagai kritik moral dan sosial yang memaksa umat beriman untuk berpartisipasi dalam memerangi korupsi dan suap. Interdisipliner juga merupakan metode yang diterapkan dalam penelitian ini. Ini mencakup eksposisi data ekonomi PDB, interpretasi teologisnya berdasarkan kisah Nabot dan raja dalam Perjanjian Lama, dan teori bidang tindakan strategis. Artikel dimulai dengan korupsi yang meluas di ASEAN, kemudian dilanjutkan dengan landasan teologis bagi peran orang percaya sebagai penjaga nilai-nilai moral dan sosial. Akan tetapi, Gereja menghadapi ritualisme dan formalisme agama yang menyebabkan nilai-nilai iman tidak memengaruhi pemeluk-Nya untuk memberantas korupsi. Dengan menerapkan teori kajian sosial Strategic Action Field (SAFs), tulisan ini mengusulkan gerakan antikorupsi sebagai tindakan strategis bagi Gereja Katolik untuk menanggulangi korupsi. Studi ini menemukan bahwa kajian sosial teori Strategic Action Field (SAFs) memungkinkan Gereja untuk mengembangkan gerakan antikorupsi sebagai tindakan strategis untuk menciptakan karya pastoral untuk menanggulangi korupsi.
\end{abstract}

Kata kunci: Gereja ASEAN, Korupsi, Gereja Katolik, moral, kritik sosial, Strategic Action Fields

\section{Introduction}

Rampant corruption remains a significant challenge in most Asia governments that weakens and sabotages their country's development. Corruption is a complex issue because it relates to nepotism, kinship ties, bribery, and poor law enforcement for financing transparency in the public sector. Moreover, business people and government workers seem to be not interested in eradicating corruption because most of them have taken advantage of the corrupt culture. Although the Global Corruption Barometer (GCB) result in 2020 shows improved trust in government institutions and their ability to tackle corruption, most ASEAN countries still have low Corruption Perception Index scores (CPI). This interdisciplinary research will provide the biblical and theological basis as the foundation for the Church to participate in how to tackle the problem of corruption. The Church has to teach believers that 
corruption is against the Catholic morality and they have to avoid it. This study also offers the Strategic Action Field (SAFs) theory as an effective way to combat corruption in Indonesia.

\section{The Rampant Corruption in ASEAN}

ASEAN region is the most growing economy worldwide, and a lot of foreign investments bring their money to Southeast Asia recently. Association of South East Asian Nations (ASEAN) started in 1967, and the members are Brunei Darussalam, Cambodia, Indonesia, Philippines, Singapore, Lao PDR, Thailand, and Vietnam. As a group, ASEAN forms the seventh-largest economy in the world with an average GPD growth rate of 4,8\% in 2019 (Schoeberlein, 2020, pp. 1-19). Despite the economic and social growth, most ASEAN countries face the same problem of corruption. Although the governments have reformed their legal governance, some countries still struggle to tackle it. The challenges are inadequate checks and balances, a low level of government transparency, and too much bureaucratic power in elites' hands (Julia Horowitz, 2019). The poor performance of governance and the rule of law are portrayed in the World Justice Project's 2020 Rule of Law index. Only three out of ten ASEAN countries scored above 50/100. The higher CPI score indicates a country has less corruption. CPI stands for Corruption Perception Index. Performance of ASEAN countries over time show some improvements and setback. Three countries have improved between 2014 and 2019: Indonesia +6 on CPI scores, Vietnam +6 , and Myanmar +8 , while two have decreased: Philippines -2 , Thailand -2 ; two countries not much changed: Cambodia -1 and Malaysia +1 (Schoeberlein, 2020).

Table 1. CPI Score in five members of ASEAN

\begin{tabular}{lll}
\hline No & Country & CPI score \\
\hline $\mathbf{1}$ & Singapore & 85 \\
\hline $\mathbf{2}$ & Brunei & 60 \\
\hline $\mathbf{3}$ & Malaysia & 51 \\
\hline $\mathbf{4}$ & Indonesia & 37 \\
\hline $\mathbf{5}$ & Vietnam & 36 \\
\hline
\end{tabular}

\begin{tabular}{lll}
\hline No & Country & CPI score \\
\hline 6 & Thailand & 36 \\
\hline 7 & Philippines & 34 \\
\hline 8 & Laos & 29 \\
\hline 9 & Myanmar & 28 \\
\hline 10 & Cambodia & 21 \\
\hline
\end{tabular}

Only Singapore obtains on the top third of the ranking, 12 out of 128 countries; while other ASEAN countries stay in the middle and below: Malaysia (47), Indonesia (59), Thailand (71), Vietnam (85), Philippines (91), Myanmar (112) and Cambodia (127). The poor performance of governance is mostly influenced by private entities providing political funding. In Indonesia, the Philippines, and Cambodia, the local political office candidates rely on the financial funding by developing alliances with business people, religious leaders, and elites. In exchange for their support, the local politician provides licenses, advisory positions in government and governmental contracts (Schoeberlein, 2020, p. 6).

The condition above is defined as "crony capitalism", a condition when patronage and personal relationship determine who get access to contracts and economic resources. The connection is not based on professional ability and transparent competition, but the intimate relation and patron-client relationship dominate the condition of crony capitalism (Schoeberlein, 2020, p. 5). For example, in Cambodia, business people and big corporations provide fund for the Cambodian People's Party. In exchange, they get contracts and access to economic recourses that would benefit their capital.

In connection to corruption, bribery is a common culture in the flawed bureaucratic system. Citizen has to bribe the government workers to get public services. $74 \%$ of the 20.000 surveyed participants say 
that government corruption is a big problem in their country. 1 out of 5 people bribe to access public service in their country (Transparency.org, 2020). The result of a survey in some countries in ASEAN (Indonesia, Malaysia, Vietnam, Cambodia, Myanmar, and Thailand). Based on the survey of the six surveyed countries, people say that police and government officials are the most corrupt and accept most bribery (Campbell \& Thomas, 2019, p. 11):

Table 2. Survey of the six surveyed countries

\begin{tabular}{lllll}
\hline Police & Legislatures & $\begin{array}{l}\text { President/ } \\
\text { Prime Minister } \\
55 \%\end{array}$ & $\begin{array}{l}37 \% \\
\text { Magistrates }\end{array}$ & $\begin{array}{l}\text { Judges and } \\
\text { leaders 13\% } \\
35 \%\end{array}$ \\
\hline Government & Tax officials & Local councilors & Business & \\
Officials & $39 \%$ & $36 \%$ & Executives & \\
$43 \%$ & & & $34 \%$ & \\
\hline
\end{tabular}

Along with other Southeast Asia countries, Indonesia stands out among Asian countries as one of the corrupt governments. According to the Transparency International report on 2020, almost half of Indonesia's people think that the level of corruption is worsened. Seven out of ten Indonesians say that the level of corruption increased over the previous 12 months (Campbell \& Thomas, 2019, p. 7). In the report of Corruption Perceptions Index 2020, Indonesia ranks 102 out of 180 countries, and it has CPI score 37 out of 100. Since 2014 corruption index of Indonesia never raised up and stayed at an average score between 35 to 40 (Transparency.org, 2020).

From bribery to the use of crony-relationship, corruption takes many faces in Southeast Asia. The table above shows that corruption occurs in many aspects of life and has no boundaries, including in political parties, churches, civil organizations, or any other groups. It causes financial losses, destroys the transparency in the organizational system, and most treacherously, corruption violates people's rights and infiltrates all daily lives. Even in pandemic covid-19, some of Indonesia's governmental leaders are removed from their positions because of their involvement in corruption by stealing money intended for the pandemic-19 recovery program. It is so disastrous that some government officials do not have moral integrity in their service to the public (Wahyudi Soeriaatmadja, 2020).

Intriguingly, the injustice system and corruption strike at the most religious countries, either in South America or Asia. Islam is dominant in Indonesia, Brunei, and Malaysia, while Buddhism has the most followers in Thailand, Myanmar, Cambodia, and Laos. Thus, questions arise, "Why do religious values and their dogma not impact the mentality of believers, predominantly those who serve at the governmental offices?" And, "Can the Catholic Church become part of conscience and pronounce her prophetic voice to make changes?" Related to the problem of injustice system and corruption, since 1986, Church in Asia understood the challenge of the laity to live Christian faith as a minority group in Asia: "The Christian laity is a minority in the midst of teeming millions. They face poverty, bribery, exploitation, corruption, and injustice" (FABC Papers 47, 1986, pp. 16-25). FABC is also aware that many Asian countries have increased in industrialization and economic growth. The fast economic growth impacts people to have a mentality of "getting rich fast". The consequence is the growth of corruption and bribery at all levels of governmental bureaucracy and society. The rampant corruption threatens political life's proper functioning in some Asian countries and undermines the people's trust in authority at many levels (FABC Papers 75, 1995). 


\section{Method}

This study is interdisciplinary qualitative research (Pilario, 2020; Wilfred, 2020). This article displays statistical data on corruption in five ASEAN countries. In addition, this paper examines the story of Old Testament figures and their implications in the pastoral of the Catholic Church. With the Strategic Action Field (SAFs) theoretical study approach (Fligstein \& McAdam, 2011), it is possible to find developing an anti-corruption movement as a strategic action to tackle corruption.

\section{Result and Discussion}

\section{Two stories of oppression and injustice in the Old Testament}

The book of Amos and Naboth's story apprehends the oppression, injustice problems, and corruption that have happened since human beings hold authority and power. Both stories emphasize the role of the prophets, Amos and Elia, to be part of the moral reserve the society needs to change. Undoubtedly, it shows that the prophets represent and proclaim the voice of God, condemning and indicting people who abuse their authority and power for their benefit and advantages.

\section{Naboth and the king}

The story in 1 King 21: 1-16 reflects on the same theme in Amos, the abuse of power by King Ahab and his wife, Jezebel. The story is not difficult to follow because it has a straightforward plot and shows an apparent conflict between the good guy, Naboth, and the villains, Ahab dan, his wife. King Ahab desire Naboth's vineyard because his vineyard is closer to his castle, and as compensation, he offers Naboth fair money even better vineyard if he prefers. But Naboth refuses it. He does not take Ahab's offer because his vineyard is more than a commodity. Cultivating his vineyard takes a long time, and his family had passed it down for generations. He is not interested in selling it and prefers to inherit the vineyard to his children. He knows that having a family land is more valuable than money because the vineyard is his family history and identity, which is more meaningful than himself (Brueggemann, 2000, p. 257).

Israelite land is barely sold to other people or outsiders because the land was a gift from Yahweh, and it is only sold to the people within the family circle. In the Old Testament, the land is the income, resource, home and identity ( In 1 Kings 16:24 the land of Samaria is sold to a relative Vandagriff, 2019, pp. 38-41). Naboth's view of the land is different from the king's. Ahab only sees the land as an economic value. It seems Ahab knows the Israelite laws of inherited land that protect the owner's rights. But, he hides some of Naboth's words from Jezebel by omitting Naboth's argument's keywords. Naboth said, "The Lord forbids that I should give up to you what I have inherited from my father" (1 King 21:3). When Ahab repeats Naboth's words, he only quotes, "I will not give my vineyard to you", removing the inheritance's reference right. Thus, his wife, Jezebel, wants to make the king happy by plotting to kill Naboth. She sends a letter to the village elders, telling them to have charge against Naboth for he has cursed God and the elders. She abuses the king's authority and credentials so that she can kill him without making her hand dirty. In the end, the influential person with authority wins the battle while the less lost his life.

The injustice story portrays the disordering relationship in the life of Ahab as king of Israel. First, it captures the relationship with the Israeli land. Naboth understands his vineyard is given by God as Yahweh has promised the land to Abraham. It is a gift from God and cannot be sold away. King Ahab, 
by contrast, understands the land as a commodity. People are free to trade and sell their land as property. Second, it relates to the meaning of the Israeli king. People see the monarchy that represents God's authority as a guide and helper for ordinary people embody the commandment. However, Ahab uses the throne as a means for himself to acquire whatever he like by force (Wells, 2013, pp. 32-35). The story tells us that justice unravels when people lose sight of who they are concerning God and others. It highlights Ahab's greed and Jezebel's abuse of power which are offensively co-opted to crush the most indisputable rights (In a limited system to store money and wealth, the land is the income and resources, also home for Israeli. It is their fundamental right to keep their land - the ground even a symbol of blessings from God Baretz, 2015, pp. 224-225). The fundamental injustice is that his wife abuse his power by killing an innocent life. In the story, her wickedness reaches its peak as she manipulates Israel's sacred tradition and makes a contempt of the justice system by creating a phony account, while Ahab lets his eyes blind to her dreadful work (Baretz, 2015, p. 225).

Elijah proclaims the message of Yahweh when widespread social immorality occurs in the kingdom of Judah. His role as the social critic places Elijah must confront openly with King Ahab. The prophet criticizes Ahab because he could not become a moral example for people in his kingdom (Baretz, 2015, p. 229). Ahab is passive and keeps silent in the case of Naboth's murder. Ignorance is no excuse, and it is a sin! As a king, Ahab bears responsibility for the crime committed in his name. Elijah asks Ahab to the point, "Would you murder and take possession?" (1 Kings 21:19). After Ahab hears Elijah's words, he confesses his transgressions and mourns for his sins.

Amos and the unjust people

Amos is a peasant from a simple family in Tekoa, and he has never been in the school of prophets and has no political background. He brings God's message to the eight kingdoms of his day that they must repent from their unjust behavior toward the people. Thus, he warns that God will punish them unless they confess their sin. Am 2: 6-16 depicts the suffering of the poor people under the tyrants. It shows the problem of social injustice in Israel and Judah, "Those who trample the head of the poor into the dust of the earth and turn aside the way of the afflicted; a man and his father go in to the same girl, so that my holy name is profaned" (Am 2: 7).

Throughout the book of Amos, the authority abuses his power by repressing the poor and the low: the innocent are sold for money (2:6); they lack of mercy in their loans to the needy (2:8); taxes and fines are misused for their interests (2:8b); and the unfair trials in the court (5:12). Although his message directs to the unjust primarily, he also speaks of hope and consolation for the people: "In that day I will raise the booth of David that is fallen and repair its breaches, and raise its ruins and rebuild it as in the days of old" (9:11).

Amos criticizes hypocrites for carrying out religious rituals, but they commit crimes against the poor. For instance, in the Jewish religious feast, Jews are forbidden to buy and sell on the first day of the month (The rampant corruption has inspired many Latin American theologians to reflect on it and relate it with the Church and theology's role in tackling the problem. Southeast Asia has the same corruption problem, but we barely find any theological reflection on it based on the Asian perspective. One example is Ruth Alvarado, a theologian from Peru, working for a faith-based human rights organization that seeks justice for the poor. Ruth Alvarado Y, 2017, pp. 29-44). However, the merchants do not want to lose their money and income. Thus, they continue to open the granaries, although it is the day they have to close. At worse, they commit scams: using dishonest scales, boosting the weight, 
and practicing harm for the poor and the needy (8: 5-6). The influential Jews take advantage of the weak and abuse them. What they have done is unacceptable in the eyes of God. They sell wheat for a higher price than the worth of it, and even they steal the food that belongs to the poor. Amos sees that if Israel continues to the current unjust behavior in his third vision, God will not forgive no matter what; Israelites will be destroyed (7: 7-9).

Acts of corruption must be punished according to the formal laws. Amos sees corruption as people who use their power to benefit their own lives without having concern for the common good. Those who have power seem to have double lives, faithful in God's duties in their religious aspects, but dishonest in their daily life and oppressive in their behavior to others. The Book of Amos offers a panorama of the poverty and oppression in his time. The poor depend on others' generosity, while the rich commit to accumulating the resources for their benefit. Some of the wealthy people provide service better if they accept dirty money, bribes for the services. They neglect others' wellbeing so that those who don't have resources cannot stand on their dignity.

Amos' message emphasizes the issue of ritualism. In ritualism, religious values and dogma are only pertinent in ritual and sacramental life instead of social, personal, and spiritual aspects. People tend to divide between their religious life and social life because both have their way of thinking and values in their world view. Prayers, offerings, and rituals have rarely affected personal and behavior in social and political actions. Indeed, Christians are called to integrate their spiritual, moral dan social values so that what they do to others reflect their love of God, as the greatest law of Torah says, "Love your neighbor and love your God with all your soul, with all your heart, and with all your mind" (Mat 22:37). Ritualism and issues of corruption, bribery, and injustice in society lead us to the discourse of ritualism and corruption.

\section{Corruption and Ritualism}

Corruption is a problem for humanity. It is about getting a "rich fast" mentality. According to FABC, corruption in Asia had weakened political work function and therefore reduced public trust toward leadership authority in society (FABC Papers 75, 1995). The question about religion as a source of human morality comes into consideration when people understand corruption. However, Leila Shadabi (2013), in her comparative study on corruption in 100 countries in 2000, finds that religion does not have any significant impact on corruption. While people in common argue that religious orders support personal morality, it can help them avoid immoral actions, but its effect is questionable in the corruption case.

Paldam in his article Corruption and Religion, Adding to the Economic Model shares this phenomenon that Protestant is correlated with less corruption compared to Catholic. In the other article, rather than questioning the impact of religion on the corruptive tendency, Dreher emphasized the political, historical, socio-cultural, and economical aspects (Dreher, Kotsogiannis, \& McCorriston, 2007). His social research finds that a study on the relation between religion and corruption has a less significant correlation, especially in a religion that has a less impact on bordering people from corruption, including the Roman Catholic faith. Another researcher, Uddi Sommer and his companions have another conclusion. They conclude that religious suggestions toward state institutions have systematically reduced the level of corruption in some conditions. While in the democratic context, corruptive behavior decreases because of the communal perception that corruption is unethical and inappropriate, in a non-democratic context, corruptive behavior is not always viewed as unethical 
(Sommer, Bloom, \& Arikan, 2013, p. 301). Within the context of the Catholic Church in Asia that promotes the dialogue with the reality of poverty, the Church must speak up the issue of corruption in Asia that significantly impacts people's economic wellbeing.

In 2005, Sidang Agung Gereja Katolik Indonesia/SAGKI (the Indonesian Bishop Conference) had formulated the term "religious formalism", referring to a formalist or legalist way of living the Catholic faith. Indeed, believers follow their religious rituals, but they give less attention to religious morality and life values in daily life. Religious formalism can be illustrated as pseudo piety. Such way of living may lead the Church to come into danger. Indeed many rituals have been implemented in daily life, but believers' lives do not align with religious morality. Therefore, religious formalism endangers our moral improvement and cannot support human beings to their best in society (Suraji, 2019).

Merret explained the formalism has a similar tendency to ritualism. A ritualism over stresses the ritual element in religion. There is a contradiction between the outward sign and inward grace. While such a community of believers or people tend to be good at their religious life because of their obedience toward religious rituals, their moral values are unparalleled with the values promoted by religious belief (Marett, 1934, p. 310). Frederikus Fios (2014) criticized religious formalism since the religious adherents tend to have rituals orientation, and therefore religion loses its significance in the real life. In a society where people still believe religion is a source of morality, religion has a prominent role as the foundation for morality. Unfortunately, religious formalism and ritualism have hijacked religion's capacity, and it merely becomes means of ritual action without having the power to change people's morality and society.

\section{Anti-Corruption Movement as the Strategic Action Field}

While in the communal perception, religion has no significant impact on reducing corruption behavior, Sommer argued that religion in today's era plays a more prominent role in worldwide politics. People can notice that there are still some religious movements in the Middle East, several political religiousrelated violence in Europe, and religious conflicts in the society. Thus, a question arises, "How can similar religious concerns be implemented in the anti-corruption movement?" Sommer concludes:

As the findings of this study illustrate, some of the implications of religion within the political realm may, in fact, be positive. At least as far as corruption is concerned, religion's effects on politics are conditional on the institutional framework in place. Religion as such does not have the power to purge the political system of corruption. Yet with the appropriate institutional platform, religion may be instrumental in the eradication of corruption. (Sommer et al., 2013, p. 302)

Within the social consideration above, religion as the source of moral values can develop believers' morality barriers against corruption. The Catholic Church in Asia, thus, needs to emphasize the anticorruption movement as a collective goal.

The Church, in the beginning, should evaluate the idea of "dialogue with the poor" as a part of triple dialogue theology in how being Church in Asia: dialogue with the poor, dialogue with the plurality of religions, and dialogue with cultures of Asia. FABC Paper 130 (2010) says dialogue is a means and a way of inculturation. Mission in Asia also seek through dialogue with the diversity of beliefs, cultures, and socio-political structures. The idea of triple dialogue is developed in the FABC 1979. Then, at the FABC Plenary Assembly in 2000, the Church says "Triple dialogue that FABC developed over past thirty years... is still valid today." Dialogue with the poor should include the reflection of the role of the Church as the moral critic and an agent for tackling the corruption because corruption has a closed affiliation with the problem of poverty and an unjust social system. While mentioned a lot about the 
dialogue with the poor in Asia, FABC has only discussed corruption in a small portion. Except for the introduction of the meaning of corruption, (FABC Papers 75, 1995). In 1986, FABC delivered a message about corruption just as a short part of social problems in Asia: extreme poverty, militarization, exploitation, bribery, corruption, injustice, threat toward freedom of religion, economic domination by a few, both local and foreign (FABC, 1986).

The term "dialogue with the poor" should not connotate that the Church in herself is considered a holy entity that is totally free from the problem of corruption. There is corruption inside the Church, and She needs to confess it. Then, in her humble consideration, Asian Church with other believers may work and walk together from the same starting point and go toward an anti-corruption society as a collective goal. Indeed, corruption is a big problem in Asia, but there is not enough discussion on any FABC papers. We may question the impact of the tiny portion of the debate in how the Church in Asia will tackle corruption as a social problem. Therefore, this study proposes a roadmap for the Catholic Church in Asia to develop the anti-corruption movement as the strategic action to create pastoral works to reduce corruption.

Strategic Action Field (SAFs) is a theory regarding collective actions within a social structure coined by Neil Fligstein and Doug McAdam. It is a system in which actors within a social network relate to each other, either individually or collectively. A social structure can be taken for granted and it works for a long time, such as a nation or a tribe. However, in a society, a social actor as agent should arise to provide people a communal ground and to attract them to share their social identity or social structure. The social structure may be actualized in a group such as a motor genk, a political party, or a particular group with a specific plan: protesting against the government, an ecological supporter, or an AntiCorruption movement. A shared understanding of the purpose bridges the social relationships for each SAF is always correlated (Fligstein \& McAdam, 2011, p. 3). Fligstein and McAdam (2015) explain the SAF theory as a meso-level theory within a broader environment where any given field is embedded and always shapes its existence.

They divide SAF actors into three categories: incumbent, challenger, and the governance units. The incumbents are those with the highest domination within a field. Usually, they control the interest of the group (Fligstein \& McAdam, 2011, p. 5). They dominate the power and authority but simultaneously should keep their control. On the other hand, the Challengers hold less power domination, with primarily incumbent defeats them. While incumbents are struggling to maintain their dominance, the challengers fight to take it over. The third actor is known as the governance unit. They keep stabilization of a structure. They manage the rules of the field and facilitate the functioning and reproduction of the system (Fligstein \& McAdam, 2015, pp. 13-14). These governance units do not play a neutral role but predominantly support the incumbent. Their rule is usually to maintain functioning and field reproduction (Fligstein \& McAdam, 2015, p. 77).

SAFs theory explains power contention among social actors within a particular social structure as a collective action unit. This theory explains how a new meso-level social orders are produced and maintained. It enables us to grasp a picture of the work of social structure (Fligstein \& McAdam, 2015, p. 31). On producing new alternative logic or reproducing the old logic of field, this theory notices the role of the skilled strategic actor(s): an actor with a particular ability to maintain or challenge the existing logic. They exist both in the incumbent and challenger. Their main task is formulating specific ideas that strengthening the position of the incumbent or challenger. On the incumbent's side, they maintain the domination either by keeping the old logic or offer the new one. On the challenger's side, their task 
is to construct a new logic of action to challenge the one belongs to incumbents (Fligstein, 2001, p. 108). Their main task is to attract people to have a shared-logic.

Fligstein and McAdam (2015) acknowledge social life as a social construction. Authority is a result of contestation of power to rule and give meaning to the people. In this idea, either incumbents or challengers consistently reproduce the social field. Generally, the reproduction of areas depends on the incumbents, but an alternative could be possible, especially in a crisis. The skilled strategic actors play their role in directing social imagination to maintain the old or issue the new systems of meaning. They provide a field of action (social construction) for as many as members of a social group.

Within this social construction, authority results from power contention to rule and give meaning within a social construction. Influencing people is about collecting authority to define what kind of social order worth doing. At least four actions enable a skilled strategic actor(s) to increase their jurisdiction: framing, agenda-setting, brokering, and robust action. These actions provide collective imagination that meaningful to a large number of actors (Fligstein \& McAdam, 2015, p. 51). By doing social framing, an actor provides people with a new logic of structures to unite people with diverse logical thoughts to share a common understanding. Skilled strategic actor(s) does agenda-setting in convincing others that a specific goal could be reached within particular collective action(s) (Fligstein, 2001, p. 114). Brokering a social actor criticizes such a social structure's old logic and offers a new collective identity and reason of action. The term "robust action" refers to a single action that can serve double meanings. On the one hand, this action could help the old logic of action, but on the other hand, this robust action also serves the new reason (Padgett \& Ansell, 1993, p. 1263). This action supports a social change with a smooth transition.

These four actions convince others about promising action for their future to keep the peace or protect a whole structure from inevitable collapse. A skilled strategic actor(s) persuades others that a new social change does not serve only their own narrowly self-interest but also a community's interest. A smooth transition is needed since if they do an action with selfish purposes, people easily deny their proposal. However, if they appear to be open to other's needs, it is difficult for them to keep their agenda (Fligstein, 2001, p. 114). Their focus is not exclusively on evolving collective ends but also on changing their planning to achieve their final goals. Fligstein (2001) concludes that "Skilled strategic actors behave more or less with the opposite motivations of rational actors who are narrowly pursuing their interests and goals in competition with others. Therefore, a skilled strategic actor should have a certain level of ability to reach such a level of authority and influence.

In order to framing corruption as a communal challenge and to develop a better life for humanity in Asia, here is a proposal in how the Catholic Church in Asia may develop a Strategic Action Field for the believers:

\section{Framing}

In the documents, FABC has provided a limited discussion on the term "dialogue with the poor in Asia". The issue of corruptive behavior as a source of poverty and part of a social problem has never been reflected seriously. The Catholic Church should explicitly declare, "corruption is Church's enemy", and make the issue of corruption an open public discussion. It is necessary to claim corruption is against Catholic morality. Framing is a process when believers understand that their love of God cannot be separated from the love of others. Doing justice, stopping bribery and corruption, and being honest are 
the actualization of Christian values in daily life. The piety should be translated in the social justice actions.

\section{Agenda-Setting}

Suppose the Church plans to find a solution for reducing corruption. In that case, the Church needs agendas whether to discuss corruption in the Church morality or promote an anti-corruption among Catholics in a local community. The more basic Christians communities have discuss the issue, the more impact will reach wider groups. Furthermore, the Church may put the idea into practice by asking every local diocese to develop anti-corruption agenda in their pastoral works, more specifically the plan should be actualized in the local parish and in the smaller community of believers.

\section{Brokering}

The brokering provides people with an imagination of a better Catholic community in Asia. The Church should promote a new idea of being a Catholic in Asia: "Rejecting ritualism and religious formalism." Brokering is a way to make an idea becomes viral by developing an tagline and slogan, for example, "Corrupt is not a Christian way." In the process, the Church redefines her identity as being Church in Asia by combating corruption and bribery. Believers should have reasons why they need to tackle corruption and bribery. Two stories from Old Testament, Amos and Naboth may be the best inspirations for them to understand their calling that their baptism compels believers to be prophet who proclaim social justice values. They have to share the idea that the Catholic faith does not tolerate the corruption.

\section{Robust Action}

Robust action helps Catholic Church to change the problem smoothly. The anti-corruption movement can be promoted in the context of dialogue with Asia's poverty. The idea of "dialogue with the poor" is not a new movement for FABC. It serves the old trend with a new meaning and a new preferential. When the new idea becomes more popular, FABC may develop it as a priority program. In the robust action, Asian theologians and pastoral workers, as skilled strategic actors, play their important role to bridge the old logic and the new one. The "dialogue with the poor" is translated with the action of rejecting corruption and bribery. The Church should implement the action within the organization and bureaucracy inside the Church. Transparency and accountability are the key to reduce corruption. In doing the action, the Church cannot work alone and need to work with other communities and organizations with the same agenda.

\section{Conclusion}

Corruption and bribery are social problems that the Church needs to pay attention to because of her calling to build social justice. However, it is not an easy mission because corruption has been immersed deeper in many ASEAN countries. Additionally, many people such as police, government officers, business people, and legislatures seem to be not attracted to eradicate corruption because most of them have taken advantage of it. It is getting more challenging to solve the problem when ritualism and religious formalism alight religious believers who are supposed to be moral, social, and faith values. The Church has to do more to reduce corruption. Ignorant the social reality is unethical and a sin!

The social study of Strategic Action Field (SAFs) theory allows the Church to develop the anticorruption movement as the strategic action to create pastoral works to tackle corruption. Strategic 
planning has four elements: framing, agenda-setting, brokering, and robust action. In the process of the anti-corruption movement, theologians and pastoral workers have the vital role as a skilled strategic actor who bridge the old logic to the new one. They have to teach believers that our holy Church is not immune from the problem of corruption. The Church needs to reforms herself as a way to dialogue with the poverty in Asia. That sincere consideration enables believers to tackle corruptive mentality because corruption is against Catholic faith. The movement may help believers to participate actively in developing social justice system in the society. When the Church has integrity and transparency, her voice to combat corruption will be more effective and powerful to make a better life for all.

\section{References}

Baretz, J. (2015). The Bible on Location: Off the Beaten Path in Ancient and Modern Israel. U of Nebraska Press.

Brueggemann, W. (2000). Smyth \& Helwys Bible Commentary: 1 \& 2 Kings. Macon, GA: Smyth and Helwys Publishing.

Campbell, L., \& Thomas, A. (2019). People's experiences of corruption: Implications for business in South-East Asia. Transparency International.

Dreher, A., Kotsogiannis, C., \& McCorriston, S. (2007). Corruption around the world: Evidence from a structural model. Journal of Comparative Economics, 35(3), 443-466.

FABC, I. (1986). The Vocation and Mission of the Laity in the Church and in the World of Asia (Tokyo, Japan, 1986). FABC V: Journeying Together Toward the Third Millennium (Bandung, Indonesia, 1990).

FABC Paper 130. (2010). Dialogue: Interpretive Key for the Life of the Church in Asia.

FABC Papers 47. (1986)., "The Vocation and Mission of the Laity in the Church and in the World of Asia".

FABC Papers 75. (1995). Asian Christian Perspectives of Harmony.

Fligstein, N. (2001). Social skill and the theory of fields. Sociological Theory, 19(2), 105-125.

Fligstein, N., \& McAdam, D. (2011). Toward a general theory of strategic action fields. Sociological Theory, 29(1), 1-26.

Fligstein, N., \& McAdam, D. (2015). A theory of fields. Oxford University Press.

Julia Horowitz. (2019). Transparency International.

Marett, R. (1934). Ritualism as a Disease of Religion. Folklore, 45(4), 310-316.

Padgett, J. F., \& Ansell, C. K. (1993). Robust Action and the Rise of the Medici, 1400-1434. American Journal of Sociology, 98(6), 1259-1319.

Pilario, D. F. E. (2020). Interdisciplinary Perspectives and Approaches in Theologizing in Asia. International Journal of Indonesian Philosophy \& Theology, 1(1), 27-40. doi: 10.47043/ijipth.v1i1.4

Ruth Alvarado Y. (2017). Facing Corruption Today in Light of the First Testament (Amos 8: 1-7). Journal of Latin American Theology, 12.

Samuel Wells. (2013). "Naboth's Vineyard and God's Justice: Forgiving Ahab,." Christian Century.

Schoeberlein, J. (2020). Corruption in ASEAN.

Sommer, U., Bloom, P. B.-N., \& Arikan, G. (2013). Does faith limit immorality? The politics of religion and corruption. Democratization, 20(2), 287-309. 
Suraji, R. (2019). FORMALISME KEHIDUPAN BERAGAMA (Studi Kasus Gereja Katolik Keuskupan Purwokerto). LOGOS, 14(1), 29-40.

Transparency.org. (2020). Asia. Retrieved May 5, 2021, from Transparency.org website: https://www.transparency.org/en/gcb/asia/asia-2020

Vandagriff, M. (2019). A modern rendering of Naboth's vineyard. Review \& Expositor, 116(1), 3841.

Wahyudi Soeriaatmadja. (2020). Https://www.straitstimes.com/asia/se-asia/indonesias-social-ministernamed-suspect-after-bribery-raid.

Wilfred, F. (2020). Asian Theological Ferment (For Doing Theology in Contemporary Indonesia: Interdisciplinary Perspectives). International Journal of Indonesian Philosophy \& Theology, 1(2), 73-90. doi: 10.47043/ijipth.v1i2.11 